\title{
A CRITICAL REVIEW OF GOVERNANCE IN THE DIGITAL ERA: A DEVELOPING NATION'S PERSPECTIVE
}

\author{
Ankit Kashyap \\ Assistant Professor, Amity University, Email-ak.ankitkashyap@gmail.com \\ Dr. Mehak Jonjua \\ Associate Professor, Amity University, Email- mjonjua@amity.edu
}

\begin{abstract}
'The best argument against democracy is a five- minute conversation with the average voter' is a famous quote by Winston Churchill. The statement also indicates the success or failure in any form of government depends primarily on voters and not on parties or politicians. The sustenance of a government in a democratic set up and in the age of anti-incumbency is viable only if it has the mandate. The current government in the territory of India is thriving despite a strong effort by the opposition to come together and stand against the government. The last two Lok Sabha elections held in 2014 and 2019 in India has been exemplary from the perspective that it has largely been Bhartiya Janata Party versus all other political parties unlike previous election where there have been contest between ruling and opposition parties. This paper aims to review the functioning of the incumbent government in last five years from manifesto till its implementation. The paper also aims to review the different policies launched by the government and its outcome. The paper will also examine how government took some landmark decisions that witnessed mass protest and may prove fatal in times to come.
\end{abstract}

Keywords- Democracy, Voters, Lok Sabha Elections, Social Media, Policies, Governance, Narendra Modi

\section{INTRODUCTION}

Indian democracy seems to have been witnessing variety of changes especially in political context. The ongoing decade and in particular last five years brought revolutionary changes in political scenario. Indian political system endorsed never before phenomenon from getting the highest number of seats in Assembly elections to formation of government with amazing permutations and combinations. The coalition government seems to have redefined its meaning in many states of India (Ratna, 2007). It is believed that the formation of any government depends on several factors such as campaigning, choice of candidates, election manifestos and the promises made during election campaigns. The importance of voters can never be ignored in the informed society.

Franklin D Roosevelt rightly quoted the importance of voters while referring to his own states that the ultimate rulers of our democracy are not President and senators and congressmen and government officials, but the voters of this country.' The voters on the other hand are more aware, smart and have variety of sources to judge their ability. The chances of them being manipulated through different forms of media is also very high because of the agendas being set by the media houses. One of the key changes in the modern politics is the growth of social media which enables politicians to be in touch with their voters directly and the level of interaction have become more impersonal or intimate (Biswas, Ingle, Roy, 2014). The voters also rely on multiple factors right from the image management of the politicians by media houses to the promises made in the form of manifestos and also during the campaigns and rallies by different political leaders.

The political dynamics, however, will be interesting to note in the current scenario where elections have taken place with limitless promises to the electorates. The audiences, in return have expectations from central and state governments. As we are aware of the fact, political dynamics talks about the relation between the political parties and the voters so it is not possible to get away with the same in democratic set up (O'Cass, Pecotich, 2005). The anti-incumbency factor plays crucial role in deciding the fate of the political leaders largely on the basis of promises made and 
achieved subsequently. Apart from the study of achievements and failures by the political parties, it is equally important to review the policies of the government launched during their tenure. Critics have always raised concerns in successful ruling of any democratic setup if it lacks political will.

The schemes of the central government and the state government supported by the central government is also a powerful indicator of the intentions of the government. The policies and schemes are announced keeping in mind the needs of larger sections of the society (Kumar, 2019). Historically, there have always been criticism if anything is introduced in the parliament. The reason for the same is obvious from the understanding that if it serves the purpose of the majority of the population, the government is able to create a strong goodwill amongst the prospective voters for the upcoming elections. Every government tries to highlight the long pending issues and bills to be passed during their tenure so that they can get credit for the same for the decades to come. It is always a healthy situation if the areas related to poverty, unemployment, health, water, electricity, sanitation, roads, education etc. gets improved under the leadership of any politician or political parties or the government as a whole.

The article aims at reviewing the first tenure of current Bhartiya Janata Party government to understand the nuances of the policies announced and the actual success attained through various schemes. The success of any scheme more or less depends on whether the average population of the nation has supported the same or not (Mc CONNELL, 2010). The review of the different policies launched during last five years will give a detailed analysis of success or failure of the government. The winning of last Lok Sabha elections is also an indicator that the audience also look for alternatives in the form of strong opposition so that they can think twice before casting their votes. The general elections to Lok Sabha accounts for a larger sample size and their mandate is the opinion of the people or the voters to be preciser (Mandikandan, Anandaraju, Karthikeyan, 2020). When it comes to formation of a government for next five years, it is imperative for the voters that they are convinced in their mind about who would rule the nation? Despite an array of teams rather unification of political parties happened before both the Lok Sabha elections, the opposition could not form the government even while giving new terms to Indian politics such as Mega-Coalition or Mahagathbandhan. The brand Modi never looked back and they formed the government with thumping majority in 2019 elections held last year.

\section{From Manifesto to Manifestation}

The effectiveness of government's functioning is normally assessed by the development achieved during the tenure of the government. Although there are no fixed parameters to check the development index within a stipulated time frame but there are certainly some visible and non-visible factors which give an idea about the achievement of the incumbent government. Some prominent factors include GDP of the nation, developments in the field of agriculture, education and industry (Biswas, 2019). Other factors which are responsible for strengthening the image of the government might include quality of life of an individual, level of satisfaction from the government and belief that the government is working for the people and will continue to do same.

Every government looks at the negative areas of the existing government and promises to change the same if they come to power. All these 'future' promises are released by different political parties in the form of what we popularly known as Election Manifestos. Election manifestos contain every element which the government targets to achieve in their five-year term. These manifestos are not just the written material in the form of a booklet but they also are an integral part of all election campaigns and they keep highlighting the important features to lure the voters (Azam, 1977).

\section{Election Manifesto 2014}

A quick analysis of election manifesto of Bhartiya Janata Party will enable us to know the level of commitment by any political party before and after the elections. The Bhartiya Janata party started 2014 manifesto by declaring UPA rule for ten years as 'Decade of Decay' by criticizing how government failed in coming up to the expectations of the voters and how they failed miserably in every fields be it governance, diplomacy, foreign policy, 
economy, border safety etc.(BJP Election Manifesto, 2014).

If any government manages to keep what they promise in their manifestos, there will different positioning of our nation at global platforms. The last manifesto released by BJP was full of promises and it covered almost every aspect what was required for the development of any state. According to Bhartiya Janata Party, price rise of essential commodities crippled every household budgets and their government will ensure checks on inflation of essential products by keeping an eye on black markets and hoarders (Kumar, 2015). The manifesto also promised to increase employment opportunities for the youth by creating skill centers across nation and enhancing job opportunities in both agricultural and industrial sector. The manifesto also blamed Congress led UPA government for dragging the nation for 10 years of jobless growth.

About the corruption, the manifesto stated that they will establish a system which eliminates the scope of corruption. However, corruption is one sector where any government will have to think many folds before blaming others for corruption related activities. With great power comes great responsibility seems not more than a statement in nation like India (B.S, 2014). Looking at the trend in last so many decades, one can easily reach to conclusion which might not be favorable to politician but it clearly indicates paraphrasing of the existing statement and it goes like 'with great power comes great corruption'. One important and much talked about promises of every government's manifesto has always been the issue of Black Money supposedly kept in international banks. Bhartiya Janata Party was no different in this issue and they mentioned in their manifesto that "BJP is committed to initiate the process of investigation and tracking down and also bringing back black money stashed in foreign banks."

The government also aims at improving public service at different governmental organizations and removes bottlenecks and missing links. As per manifesto, government wants to improve center-state relations by extending maximum cooperation and clearing the long pending issues. The state of Jammu and Kashmir and its relates issues like abrogation of Article 370, return of Kashmiri Pundits and Pakistan Occupied Kashmir region also found place in BJP manifesto (I.-A. N. 2014). A lot of emphasis was laid for bringing good governance by taking control of different departments which are under scanner. The manifesto also focused on making changes in electoral reforms so that politicians with criminal background can be eliminated from politics.

Apart from these important agenda, there were several other elements which figured ranging from education for all, security and rights for senior citizens, women reservation rights which is a long pending issue with the parliament, promotion of all forms of sports, vocational training, improvement in health services and opening of medical colleges and hospitals for affordable treatment from $t$ for all, development of agricultural and railway infrastructure. In last four years of the incumbent government, there have been lots of positive and negative criticisms about the promises made while drafting the manifestos and promises kept till date (Shah, 2019).

\section{Promises: Over-Promised and Under- Delivered}

The political system in any democratic setup is very challenging mainly because they need to meet the expectations of millions of people. The expectations however are not something which gets erupted naturally. They exist because the same is created in the minds of the electorates with endless promises made to them during election campaign or immediately before elections. As discussed above, like any other government, Modi or BJP government also promised a lot during 2014 Lok Sabha elections in their political manifesto and also during their election campaigns. As the incumbent governments completed four years, there have been numerous opinions and report cards prepared for the government (Dutta, 2018). While some believe that the promises are under delivered others think that the government has fulfilled many and the best is yet to come as it takes time for any government to achieve a set target. We will see in this section whether government actually managed to benefit people or the promises were just promised. 
In the article published in Hindu titled, "Modi's election promises remain on paper, says Narayana", the focus remained on the failure of BJP government as they failed to keep important promises especially when it comes to getting back Black Money stashed in international banks (N.D, 2017). The government was also criticized for taking Uturn on the matters of GST and nuclear power. CPI national secretary $\mathrm{Mr}$ K. Narayana also laid emphasis on government's failure in funding to state government for infrastructural development and thanked people for not protesting for the biggest failure of the government in the name of demonetization.

The Brand Modi is active on social media which is evident from the list of followers on different networking sites. Any small incident in PM Modi's life is glamourized and criticized subsequently. An event like his birthday is bound to be celebrated in larger scale. Followers as well as critics, ruling as well as opposition wished and congratulated him for his achievements in last 4 years as Prime Minister. While supporters left no stones unturned boasting about his accomplishments, critics reminded him about the promises which have yet not been delivered alongside wishing Mr. Prime Minister. The Free Press Journal in an article listed promises which have not been delivered by Modi government and the tenure is about to complete (Mastakar, 2017). The important promises which remained undelivered included no action passed on Uniform Civil Code which was one of the most important agenda before the formation of the government, employment promise, Ganga clean-up plan which was related to his constituency Varanasi only. The other agendas where government was criticized included Swachh Bharat Abhiyan where no concrete action has been taken to bring out the changes, peace and harmony in the society which was highlighted in the manifesto of the BJP government. Almost every critic focused on the promise of 15 lakh rupees in every individuals account by putting a raid on black money (India Today, 2019).

As the time progressed and BJP government completed four years and are serving the final year of their tenure, the critics have raised their eyebrows by questioning the promises made as part of election manifesto. In an article published in Hindustan Times titled "BJP govt. has lot of ground to cover in delivering promises made in 2014", various aspects of manifesto have been identified. An in depth analysis of the development of the government in different sectors reveals that the government did try for achieving targets as promised in their manifesto released in 2014 (Economic Times, 2018).

On certain aspects, the government has been able to deliver while on certain issues, it has been a halfhearted effort. There have been some positive developments in agricultural sector, education sector, and development of women by starting campaigns on girl education, electrification of rural areas and taxation system. While many programs have been developed for upliftment of rural and urban population, there seems to be some lacunae in carrying out those projects effectively. The government had to call a high level meeting to assess the different agenda set in manifesto and targets achieved so far (Raghotham, et al, 2019). One thing which remains challenging for any government is to curb corruption. The incumbent government took strong action in the form of demonetization to analyze black money being circulated in the market and identify Benami property. Demonetization, however was criticized by opposition and the public for the problems being faced by the people and ultimately coming out with no concrete outcome of it.

Targeting at media and the functioning of the government and how different media houses chose to ignore the under performance of the government, an article titled "Modi has overpromised and under-delivered, but you may have been too distracted to notice" was published by scroll.in. It was pointed in the article that many things which were promised as part of election manifesto was not fulfilled by BJP government and how they capitalized on religion based politics. Insufficient job opportunities as against promised manifesto, electrification of villages at very slow pace, flagship Swachh Bharat program, cleaning of Ganga River are few of those initiatives of the government which is yet to witness any concrete development (Halarnkar, 2018). 


\section{DECISIONS THAT WERE DECISIVE- A STRONG POLITICAL WILL}

In the last four years of BJP Government, there has been lot of fluctuating moments where the government has been appreciated and criticized simultaneously. Some decisions which are considered as landmark may turn out to be boon for the incumbent government but it may go in other direction as well. The important decisions which impacted entire nation can be summed under the following headings.

\section{Demonetization:}

A decision taken by Prime Minister Narendra Modi that shocked the entire nation within few hours of its announcement. The term 'Demonetization' itself was unheard by more than half of the total population. The nation was exposed to radical policy move where 500 and 1000-rupee currency notes were declared invalid from midnight of November 8 . The declaration of these currency notes amounted to 15.44 trillion rupees or $86 \%$ of notes and coins in circulation (Jose, 2017). This created hue and cry situation nationwide during the initial days as these currencies were replaced by new 500 and 2000 notes which took time to circulate in the banks and apparently to the people. According to a report published by news website Indianeconomy, demonetization has lot of positive effects. It not only provided invaluable services of bringing awareness amongst public but it also led to increase in substantial number of tax payers. It promoted digitalization of the economy alongside keeping a check on fraudulent and counterfeit currencies which were being circulated cross borders (Kushwaha, Kumar, Abbas, 2018).

Demonetization produced some unavoidable negative effects in the Indian economy for short term. The GDP of the nation continued to be on the lower side for couple of quarters. The immediate problems couldn't be ruled out where people had to exchange their old currency from the banks and they stood in queue for hours and in some case the wait was never over. Demonetization acted as liquidity shock that disturbed the entire economy. However, the positive outcome of demonetization cannot be ruled out. It definitely created loss of growth momentum but in longer run it resulted in bank deposits which allowed the banks to cash out money which resulted in lowering of interest rates of the banks (Singh, 2017). Tax and credit card payments increased many folds; many violent groups' activities were notably decreased. It was looked upon as cleaning exercise that produces several good things in the economy.

\section{Good \& Services Tax:}

The incumbent government will definitely boast of this achievement that GST Bill was passed in both the houses of the parliament and it is finally an Act. Introduction of GST is is unprecedented reform in the history of indirect taxation in India. It came into effect on $1^{\text {st }}$ July 2017 but it was introduced long time back in the year 2000 only. Several governments tried to introduce GST but with failed attempt. Goods and services tax will bring an end to several indirect taxes which were collected by state and central governments (Bala, 2018).

Apart from the taxes, it will also bring an end to different forms of duties which were being charged earlier such as excise duty, basic custom duty, countervailing duty and many other forms of indirect taxes. Like any other policies, GST was also looked upon by the critics and they said it further requires lot of changes. Many tax slabs were subsequently altered by the government as and when the situation demanded. GST tax slabs were pegged at $0 \%, 5 \%, 12 \%, 18 \%$ and $28 \%$ for different items as suggested by the government and the standing committee (Garg, 2016). The positive side of GST includes single taxation system which will hopefully bring an end to corrupted system as there will no longer be taxation at multiple junctures. The cost of manufacturing, production and transportation will also be minimized. On the other hand, certain negative aspect of GST cannot be ruled out as it will be problematic for many dealers who have been cheating on taxes for a long time in the name of Vat and not paying excise duties etc. Some of the basic services will be expensive as the slab of service tax will be increased immediately (Agrawal, 2017).

Prices of some products will come down while some products may be costlier depending upon the slabs they are fixed at. To conclude, the nation is witnessing the nascent stage of GST and it has been designed in such a way that in longer run it should benefit people as well as state and the central government. 


\section{Surgical Strike \& Air Strike}

The event that literally changed the trajectory for the Indian government. The time when nation was half way through Modi government and the graph of the incumbent government was declining because of inflation and terrorist attacks. Soon after Uri attack in the state of Jammu \& Kashmir by four militants, the government was being questioned for not retaliating against the neighboring country Pakistan even after frequent ceasefire violations. However, eleven days after the attack on 28-29 September, 2016 when Indian Army conducted a surgical strike and damaged many base station of the militants, it was lauded by everyone (Sen, Masoodi, 2016). Initially, there were questions raised by the opposition demanding for footage as it was denied by Pakistani Government that any such strike took place. But later on, even the opposition praised the action taken by Prime Minister Narendra Modi in consultation with other ministries like Home \& Defense. This strike was referred as one of the boldest step taken by Prime Minister so far and it escalated the graph of popularity to large extent and act as booster for upcoming elections (Ghosh, 2016).

When the nation was geared up for upcoming elections, an incident that shook the entire nation was Pulwama Attack on February 14 killing more than 40 soldiers of Indian Army as their convoy was attacked by suicide bombers. This incident was not only condemned by everyone but it also increased the challenges for the government. It may be referred as vote bank politics, showing strength of a nation or political will, but the government planned a retaliation within days and executed Balakot air strike within twelve days (Haider, Peri, 2019). Though the air strike claimed by Indian air force and the government remains controversial till date as Pakistan says that no damage has been done by Indian Air Force and in contrast Indian government claims to have destroyed multiple base stations. The return on Abhinandan Varthman from Pakistan's custody was also welcomed by every citizen of the nation and it turned out to be one of the biggest achievement of the government. Needless to mention, it attracted huge vote banks in support of the government (Banik, Raman, 2019). The social media in both these cases acted as a great tool for disseminating information, however there were certain reports of fake videos also being circulated through digital media.

\section{POLICIES THAT MATTERS \& THEIR DISSEMINATION THROUGH DIGITAL MEDIA}

Pradhan Mantri Jan Dhan Yojana (PMJDY)

A unique initiative by Narendra Modi government to ensure and provide banking services to every household of the country. Jan Dhan Yojana is a national mission to bring comprehensive financial inclusion. In this scheme, any person above the age of 10 years is allowed to open a bank account without any hassles. One of the key feature of this scheme is that one can open the account without depositing any money and further no minimum balance is required to maintain the account if it has been opened under PMJDY. The scheme was launched on August 28, 2014 and have witnesses more than 40 crore beneficiaries so far which shows the popularity and success of Jan Dhan Yojana. The scheme was targeted mainly for the people belonging to Below Poverty Line but was subsequently beneficial to everyone who was not having a bank account (Economic Times, 2020).

The Jan Dhan Yojana account can be used for savings, issuance of credit and debit cards, remittance, pension, insurance etc. in easy manner. The government also plans to use this account to transfer money to the account holders directly if any scheme has been launched by the government to support any class of the society. Since the launch of this scheme, government has transferred money directly for any relief assistance to farmers, senior citizens or during course of any natural calamity. Jan Dhan Yojana eliminated the role of mediators who used to distribute money on behalf of the government and it was always criticized that some beneficiaries did not receive any grants sanctioned by the government. Despite the fact that Jan Dhan Yojana account holders are not required to keep a minimum balance, it is surprising to see that the total balance in Jan Dhan Account stands at whooping 119,706 crore by the end of financial year 2019 which indicates that people develop saving habits if they have a bank account which is always healthy for any developing nation and economic conditions of the country. The role of social media in 
creating awareness is inevitable as it got disseminated through different forms of social media and PM Narendra Modi himself announced the launch of such policies through his Twitter and Facebook account.

\section{Pradhan Mantri Sukanya Samriddhi Yojana (PMSSY)}

For a nation to progress, it is inadvertently important to bring equal status to everyone in the societal structure. Unfortunately, declining sex ratio and continuation of patriarchal society reflected the realms of sufferings by the women of the nation. In order to strengthen women empowerment and abolish any form of female feticide, government launched an interesting scheme for the betterment and upliftment of girl child. Pradhan Mantri Sukanya Samriddhi Yojana was launched on January 22, 2015 to ensure the future of girl child. Under this saving schemes for girl child, one can deposit a minimum amount of 1000 rupees annually and maximum amount that can be deposited in the account is $1,50,000$. The important feature of this scheme is the attractive interest rates which is revised by the government as per the economic conditions of the nation(Kukreja, 2016). This scheme allows only one account per person but one can open two accounts valid for two girl child.

The savings account can be opened in the name of a girl child and one can deposit the amount for a period of 15 years and can also avail the benefit of income tax deduction under section $80 \mathrm{C}$. The girl can withdraw 50 percent of the amount for marriage or higher studies if she completes 18 years of age. After the girl completes 21 years of age from the date of opening of the account, she can withdraw the maturity amount along with the interest given by the government. The government has made certain revisions and now the minimum amount required to be submitted every year to continue with the account has been reduced to just 250 rupees a year while the maximum amount stand the same. This scheme witnessed grand success because of the high interest rate being provided by the government and more than 1.5 crore accounts have been opened under this scheme with a deposit of more than 31 thousand crores by the end of 2018. PM Narendra Modi proudly announced the launch of the scheme alongside Beti Bachao
Beti Padhao scheme and posted the same in his twitter account with a picture to substantiate the launch.

\section{Pradhan Mantri MUDRA Yojana (PMMY)}

This yojana was appreciated as the main objective of this yojana was to promote micro enterprises sector. On one hand, where most of the government is normally criticized to be a puppet in the hands of corporate sector, this yojana was to encourage the growth of small corporates who are unable to fund themselves. Pradhan Mantri MUDRA (Micro Units Development and Refinance Agency) was launched with a mission to endorse funding to the non-corporate small business sector. Any citizen of India who wants to be a entrepreneur or start a small business/startups can avail loan from 50 thousand to 10 lakhs to start their business under the three Shishu, Kishore \& Tarun categories. The scheme was launched in April 2015 and it sanctioned 8.93 lakh crore amount to 18.25 crore investors in the first four financial years(George,2015). An interesting fact that was observed that out of the total beneficiaries of this scheme, 70 percent are women entrepreneurs. Like the previous two schemes, these scheme was also launched and promoted by the use of social media tools like Facebook \& Twitter. Narendra Modi has always believed in connecting to the youths directly and launch of such schemes through social media platforms ensures maxim reach, visibility and awareness.

\section{Pradhan Mantri Jeevan Jyoti Bima Yojana (PMJJBY)}

This scheme by the government of India was an initiative to provide insurance to maximum citizens at a minimal cost. Jeevan Jyoti Bima Yojana guarantees life insurance cover for 2 lakhs by paying just 330 rupees excluding applicable tax. This yojana was launched in May 2015 with a view to penetrate life insurance cover to the citizens of India. The scheme is available to any person between the age group of 18-50. It provides insurance from any kind of death including suicide and murder (Sharma, Sarathe, 2017). Since its inception, approximately 7 crore person have enrolled for this scheme. The efficiency of the scheme can be analyzed from the fact that the government has disbursed claims of 1,77,276 people out of 1,89,257 claims received. A person needs to have a valid bank account to 
avail this scheme and the premium for the insurance is auto-renewable.

\section{Pradhan Mantri Suraksha Bima Yojana (PMSBY)}

Pradhan Mantri Suraksha Bima Yojana was launched alongside Jeevan Jyoti Bima Yojana in May 2015. This yojana provides accidental insurance cover for 2 lakhs and this scheme also aims at penetration of insurance cover to larger section of the audience specially keeping in mind the increasing number of accidental deaths. The unique feature of this scheme is that it is available to all citizens between age group of $18-70$ at just 12 rupees excluding tax. It also covers insurance of 2 lakhs for permanent disability and 1 lakh for partial disability. The scheme gained popularity from the time it is launched and more than 18 crore person enrolled for the same(Deb, Sarma, 2016). The government also disbursed 39,625 claims out of 50,003 claims received. The scheme can be availed by any person with valid bank account and this scheme is also renewable.

\section{Atal Pension Yojana (APY)}

This was another Jan Suraksha scheme launched on the same date like Jeevan Jyoti Bima and Suraksha Bima Yojana. The scheme aimed at increasing maximum number of people to avail pension beneficiary specially for those people who are working with unorganized private sector companies. The scheme is available to all Indian citizens between the age of 18-40. One has to make contribution for minimum 20 years before getting the benefits of pension after attaining 60 years of age. Based on an individual contribution, the scheme provides a monthly pension of Rs 1000 to Rs 5000 per month (Arora, Kundu, 2015). Atal pension Yojana has more than 2 crore people who have enrolled for the scheme and it is increasing rapidly with increase in awareness through social media platforms.

\section{Pradhan Mantri Awas Yojana (PMAY)}

One of the greatest initiative by launching house for all by 2022 looked more than ambitious to fulfill. The scheme was launched in June 2015 and the progress since then is commendable. The government announced 5 crore homes to be built in totality out of which 3 crore homes to be built in rural areas while remaining 2 crores in urban areas. The government aims to provide these affordable homes to the people belonging to LIG and EWS categories. There are different kinds of subsidies also announced by the government for different class of the people and there are subsidies in availing home loans also which makes buying houses more affordable than ever (Waykole, 2019). The government has sanctioned 1 crore plus houses already and budget have been sanctioned for rapid progress of construction of houses under this scheme. Pradhan Mantri Awas Yojana have been successful many folds as compared to all previous schemes launched. This scheme also benefitted many other industries simultaneously such as cement, steel, daily wage laborers, real estate sector, banking sector etc.

\section{Unnat Jyoti by Affordable LEDs for All (UJALA)}

This scheme replaced the existing 'Bachat Lamp Yojana' and was launched by Prime Minister Narendra Modi on May1, 2015. This project is being taken care by Energy Efficiency Services Limited. The project is considered as world's largest project in LED distribution in non-subsidized category. The success of UJALA scheme can be estimated from the fact that it saves $47,048 \mathrm{mn} \mathrm{kWh}$ energy per year. The government has distributed more than 36 crore led lights till March 2020(Chunekar, Mulay, Kelkar, 2017). It also saved approximately 19,000 crore rupees by avoiding peak demand of $9400 \mathrm{MW}$ of energy. It also resulted in environment conservation by reducing enormous level of carbon dioxide. LED industry has sold 163.42 crore LEDs till January 2020 as per government records.

\section{Ayushman Bharat Pradhan Mantri Jan Arogya Yojana (AB PM-JAY)}

Ayushman Bharat is a flagship scheme launched by Government of India on September 23, 2018 to achieve the vision of Universal Health Coverage to meet Sustainable Development Goals (SDGs). Pradhan Mantri Jan Arogya Yojana popularly known as PM-JAY is a landmark scheme in the health sector. It is the largest health assurance scheme in the world which aims at providing a health cover of Five Lakhs to more than 10.74 crore poor and vulnerable families which is close to 50 crore beneficiaries. PMJAY provides health cover for secondary and 
tertiary care hospitalization. The scheme aims to target the bottom 40 percent of the Indian population(Yadavar, 2020). The households included are based on the deprivation and occupational criteria of Socio-Economic Caste Census 2011 (SECC 2011) for rural and urban areas respectively. PM-JAY was earlier known as the National Health Protection Scheme (NHPS) before being rechristened. There is no restriction on the family size, age or gender. The cashless access to health care services make this scheme more popular and people are getting benefitted from the same.

\section{Pradhan Mantri Ujjwala Yojana (PMUY)}

India is a land of villages not only on papers but also from the fact that 10 crore households are deprived of LPG as cooking fuel out of a total of 24 crore households. PMUY aims to provide clean cooking fuel in the form of LPG so that women and children do not suffer from health hazards caused due to smoke created by burning of coal, firewood, etc. The scheme was launched by PM Narendra Modi on May $1^{\text {st }}, 2016$ that aims at providing 5 crore LPG connections to BPL families in three years. The consumption of LPG has increased by 56 percent times in 2019 as compared to 2014.(Sen, 2018) The highly popular scheme has benefited over 14.6 million BPL families in Uttar Pradesh, 8.8 million in West Bengal, 8.5 million in Bihar, 7.1 million in Madhya Pradesh and 6.3 million in Rajasthan.

\section{Analysis of Schemes Launched}

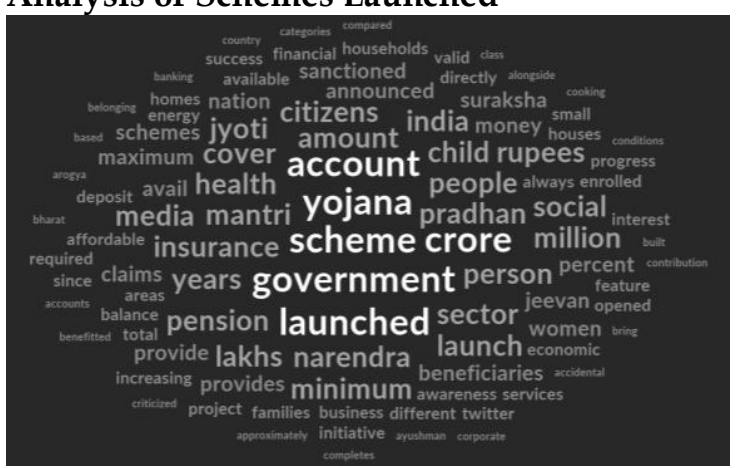

Figure-1-Word Cloud (NVIVO) representing different policies

The analysis through the above image of word cloud clearly depicts that the government launched several policies and schemes which impacted crore of Indian population. It also indicates that several citizens opened their account in banks and maintained a substantial amount as compared to the previous government. The provisions like pension, insurance benefited millions of people and also created awareness among the society. There was development in multiple sector and social media like twitter play a significant role in spreading awareness about schemes. The cloud also represents that their have been provisions for betterment in the health sector at affordable prices. The media also ensured the dissemination of information to the citizens of the nation.

\section{Thematic Analysis of Schemes Launched}

\begin{tabular}{|l|c|}
\hline & $\begin{array}{c}\text { A : Codes } \backslash \\
\text { policy }\end{array}$ \\
\hline $1:$ account/account holders & 4 \\
\hline $2:$ amount/balance & 5 \\
\hline $3:$ care & 2 \\
\hline $4:$ citizens/families/houses & 6 \\
\hline $5:$ crore beneficiaries/ \\
households \\
\hline $6:$ health/health cover & 6 \\
\hline $7:$ saving & 3 \\
\hline $8:$ scheme & 4 \\
\hline $9:$ sector & 4 \\
\hline $10:$ social media platforms & 2 \\
\hline \multicolumn{2}{|c|}{ Figure 2- Thematic Analysis using Codes for } \\
\end{tabular}

As per thematic analysis, it can be observed that with different schemes launched by the government, citizens of the nation was able to develop the habit of savings by opening accounts in the bank under Jan Dhan Yojana and overall balance in the accounts of the people multiplied. Through different schemes related to health sector, it is evident that most people are getting benefited and are happy to avail such schemes. There have also been development in many other sectors as sector has been identified as one of the important theme and with the development of those sectors, millions of population have acquired resources that they might have been looking for. One of the important theme is the use of social media platforms which actually enabled the government to launch their policies and promote their policies to desired set of audience.

The important policies can be summarized as per the table given below: - 


\begin{tabular}{|c|c|c|c|c|c|}
\hline S.No. & Policies & $\begin{array}{l}\text { Launch } \\
\text { Date }\end{array}$ & Purpose & Beneficiary & Social Media Usage \\
\hline 1 & $\begin{array}{l}\text { Pradhan } \\
\text { Mantri Jan } \\
\text { Dhan } \\
\text { Yojana } \\
\text { (PMJDY) }\end{array}$ & $\begin{array}{l}\text { August } \\
28,2014\end{array}$ & $\begin{array}{l}\text { To provide } \\
\text { banking service } \\
\text { to } \quad \text { every } \\
\text { household }\end{array}$ & $\begin{array}{l}38 \text { Crore and } \\
\text { counting }\end{array}$ & $\begin{array}{l}\text { "Jan Dhan Yojana signifies } \\
\text { our determination to end } \\
\text { financial untouchability \& } \\
\text { attain freedom from } \\
\text { poverty"- Tweet by PM } \\
\text { Narendra Modi on launch } \\
\text { date. } \\
\text { Similar and frequent posts on } \\
\text { Facebook and Twitter after } \\
\text { achieving any landmark or } \\
\text { anniversary. }\end{array}$ \\
\hline 2 & $\begin{array}{l}\text { Pradhan } \\
\text { Mantri } \\
\text { Sukanya } \\
\text { Samriddhi } \\
\text { Yojana } \\
\text { (PMSSY) }\end{array}$ & $\begin{array}{l}\text { January } \\
22,2015\end{array}$ & $\begin{array}{l}\text { To secure the } \\
\text { future of girl } \\
\text { child }\end{array}$ & $\begin{array}{l}1.6 \text { crore and } \\
\text { increasing } \\
\text { every year }\end{array}$ & $\begin{array}{l}\text { "At launch of 'Beti Bachao, } \\
\text { Beti Padhao' programme. } \\
\text { Launched } \\
\text { Samriddhi Account' for the } \\
\text { girl child"- PM Modi }\end{array}$ \\
\hline 3 & $\begin{array}{l}\text { Pradhan } \\
\text { Mantri } \\
\text { MUDRA } \\
\text { Yojana } \\
\text { (PMMY) }\end{array}$ & $\begin{array}{l}\text { April, } \\
2015\end{array}$ & $\begin{array}{lr}\text { To } r \text { promote } \\
\text { microenterprises } \\
\text { sector } \quad \text { and } \\
\text { startups }\end{array}$ & $\begin{array}{l}18.25 \text { crore } \\
\text { investors in } \\
\text { four years }\end{array}$ & $\begin{array}{l}\text { "Through Mudra Yojana, the } \\
\text { MSME sector is receiving a } \\
\text { substantial impetus. MSME is } \\
\text { a sector that is crucial for } \\
\text { India's transformation and } \\
\text { our Government is } \\
\text { undertaking a series of steps } \\
\text { and reforms to facilitate } \\
\text { further growth in the sector"- } \\
\text { PM Modi on completion of } 3 \\
\text { years of the scheme. }\end{array}$ \\
\hline 4 & $\begin{array}{l}\text { Pradhan } \\
\text { Mantri } \\
\text { Jeevan Jyoti } \\
\text { Bima } \\
\text { Yojana } \\
\text { (PMJJBY) } \\
\end{array}$ & May, 2015 & $\begin{array}{l}\text { To provide } \\
\text { insurance to } \\
\text { maximum at } \\
\text { citizens a cost } \\
\text { minimum col }\end{array}$ & $\begin{array}{l}7 \text { crore and } \\
\text { increasing }\end{array}$ & \multirow{3}{*}{$\begin{array}{l}\text { "You would be delighted to } \\
\text { know that due to the Pradhan } \\
\text { Mantri Jeevan Jyoti Bima } \\
\text { Yojana, Pradhan Mantri } \\
\text { Suraksha Bima Yojana and } \\
\text { the Atal Pension Yojana, the } \\
\text { lives of } 20 \text { crore Indians have } \\
\text { been transformed. } 52 \% \text { of the } \\
\text { beneficiaries are from rural } \\
\text { areas"- PM Modi tweeted on } \\
\text { completion of three years of } \\
\text { these schemes }\end{array}$} \\
\hline 5 & $\begin{array}{l}\text { Pradhan } \\
\text { Mantri } \\
\text { Suraksha } \\
\text { Bima } \\
\text { Yojana } \\
\text { (PMSBY) }\end{array}$ & May, 2015 & $\begin{array}{l}\text { To provide } \\
\text { accidental } \\
\text { insurance cover } \\
\text { at almost no cost }\end{array}$ & $\begin{array}{l}18 \text { Crore and } \\
\text { counting }\end{array}$ & \\
\hline 6 & $\begin{array}{l}\text { Atal } \\
\text { Pension } \\
\text { Yojana } \\
\text { (APY) }\end{array}$ & May, 2015 & $\begin{array}{lr}\text { To ensure } \\
\text { availability of } \\
\text { pension for } \\
\text { private sector } \\
\text { workers }\end{array}$ & $\begin{array}{l}\text { More than } 2 \\
\text { Crore and } \\
\text { rapidly } \\
\text { increasing }\end{array}$ & \\
\hline 7 & $\begin{array}{l}\text { Pradhan } \\
\text { Mantri } \\
\text { Awas } \\
\text { Yojana } \\
\text { (PMAY) }\end{array}$ & June, 2015 & $\begin{array}{l}\text { To provide } \\
\text { housing for all } \\
\text { by } 2022\end{array}$ & $\begin{array}{l}1 \text { crore house } \\
\text { sanctioned } \\
\text { and numbers } \\
\text { increasing }\end{array}$ & $\begin{array}{l}\text { Pradhan Mantri Awas Yojana } \\
\text { will positively impact many } \\
\text { lives \& give a boost to our } \\
\text { dream of 'Housing for All.'- } \\
\text { PM Modi }\end{array}$ \\
\hline 8 & $\begin{array}{l}\text { Unnat Jyoti } \\
\text { by } \\
\text { Affordable }\end{array}$ & $\begin{array}{l}\text { May } \\
2015\end{array}$ & $\begin{array}{l}\text { To provide } \\
\text { electricity at low } \\
\text { cost. }\end{array}$ & $\begin{array}{l}36 \text { crore LED } \\
\text { lights and } \\
\text { increasing }\end{array}$ & $\begin{array}{l}\text { \#UJALA scheme achieves } \\
\text { phenomenal milestone - More } \\
\text { than } 25 \text { crore energy efficient }\end{array}$ \\
\hline
\end{tabular}




\begin{tabular}{|c|c|c|c|c|c|}
\hline S.No. & Policies & $\begin{array}{c}\text { Launch } \\
\text { Date }\end{array}$ & Purpose & Beneficiary & Social Media Usage \\
\hline & $\begin{array}{l}\text { LEDs for } \\
\text { All (UJALA) }\end{array}$ & & $\begin{array}{l}\text { Distribution of } \\
\text { LEDs }\end{array}$ & everyday & $\begin{array}{l}\text { LED bulbs distributed across } \\
\text { India. \#BuildingNewIndia- } \\
\text { Official Twitter account of } \\
\text { BJP }\end{array}$ \\
\hline 9 & $\begin{array}{l}\text { Ayushman } \\
\text { Bharat } \\
\text { Pradhan } \\
\text { Mantri Jan } \\
\text { Arogya } \\
\text { Yojana (AB } \\
\text { PM-JAY) }\end{array}$ & $\begin{array}{l}\text { September } \\
23,2018\end{array}$ & $\begin{array}{l}\text { To provide } \\
\text { universal health } \\
\text { coverage of } 5 \\
\text { lakh per family }\end{array}$ & $\begin{array}{l}10 \text { crore } \\
\text { families } \\
\text { equivalent to } \\
50 \text { crore } \\
\text { beneficiaries }\end{array}$ & $\begin{array}{l}\text { The launch of PMJAY- } \\
\text { \#AyushmanBharat will have } \\
\text { a positive impact on the lives } \\
\text { of } 50 \text { crore people of India. } \\
\text { Such an initiative is } \\
\text { unparalleled in terms of scale } \\
\text { and extent. It shows our } \\
\text { unwavering commitment to } \\
\text { create a healthy India. Modi } \\
\text { on launch of scheme. }\end{array}$ \\
\hline 10 & $\begin{array}{l}\text { Pradhan } \\
\text { Mantri } \\
\text { Ujjwala } \\
\text { Yojana } \\
\text { (PMUY) }\end{array}$ & $\begin{array}{l}\text { May } \\
2016\end{array}$ & $\begin{array}{l}\text { To provide } \\
\text { clean cooking } \\
\text { fuel in the form } \\
\text { of LPG }\end{array}$ & $\begin{array}{l}8.03 \text { Crore by } \\
\text { Sept, } 2019\end{array}$ & $\begin{array}{l}\text { Yes, the Ujjwala Yojana has } \\
\text { furthered women } \\
\text { empowerment, especially } \\
\text { helping women from poorer } \\
\text { sections of society- PM Modi } \\
\text { on completion of two years of } \\
\text { scheme. }\end{array}$ \\
\hline
\end{tabular}

Figure 3- Tabular representation of important policies $\mathcal{E}$ the use of social media in their promotion

The above mentioned schemes are representative sample of different other popular schemes launched by the government in the first tenure of five years. These ten schemes were selected on the basis of total number of beneficiaries being directly benefitted. However, there is a long list of more than 30 schemes which were launched at regular intervals by the incumbent government in the interest of the people. The paper also analyzed that not every scheme became successful and also the utilization of the government fund did help a large section of the society but not to everyone that requires upliftment. There have been important and ambitious projects which became popular like Swachh Bharat Abhiyan, Make in India, Digital India, Cleaning Ganga and Yamuna Projects to name a few. The government has been launching projects despite lot of controversies and reactions by the opposition. While some projects benefitted the people and the society in real sense, some projects died its natural death. One significant aspect which has been observed during all these years is the excessive and impactful use of social media by the government. The social media tools like Twitter and Facebook have been used during the launch of all these schemes by the government and all these schemes have been continuously promoted on different forums of social media. Prime Minister Narendra Modi personally tweeted on the anniversaries of all these schemes and mentioned the growth curve and the number of beneficiaries gained through different schemes.

\section{CONCLUSION}

In order to understand the ruling or the perpetual performance of the government, one needs to observe multiple facets of the government which includes its governance, policies, achievements, and the reaction of the people. In a democratic set up or any kind of governmental structure, it is very important to comprehend and perceive the actual involvement of the government with its subject. One area where Modi government throughout their tenure had upper hand was the activeness of the government on different aspects and not being lethargic like the previous governance. It is the innate nature of human being that they want to see the involvement of their leaders on different occasions and also wants to witness the political will as and when required. Prime Minister should be the face of the nation irrespective of the prevalent situations in the country.

This government took numerous steps to improve the communication link between the 
government and the public hence reducing communication gaps. Ruling a quasi-federal structure like India is always challenging for a government as they have to deal with situations at multiple levels. The government took some daring steps like reforming the tax structure since independence and brought goods and services tax(GST) that witnessed immense criticisms alongside the appreciation. Demonetization of the existing currency was another big step by the government which became very problematic for the government's image as it was condemned by many include tax experts and ex RBI governors. The benefit of demonetization is still a big question mark on government's decision. The government even witnessed the brunt of the same in legislative assembly elections where they couldn't perform as per their expectations. During the rough phases of the government because of terrorist attacks, inflation or some other issue, events like surgical strike and air strike garnered support of the public to the government and it also united the nation for a cause. It is very important that the equilibrium of belief system is maintained through proper communication channel. The frequent interaction with the general public of the nation through different social media platforms and replying individuals on personal basis made the government more popular as compared to previous governments. The transparency enhanced as people got their tools to connect with the government and anticipate the government to act on the same.

The government also launched enormous schemes to support farmers, non-pension holders, future entrepreneurs, electrification of houses, providing smoke free cooking gas in the form of LPG to all the household living below poverty line. Some schemes directly benefitted the people and they are still being benefitted, some schemes like Swacch Bharat, Digital India, helped in unification of the public and they all stepped forward to support the government, while some schemes remain puzzle for all those people who were supposed to be getting benefits from the scheme. To conclude the five years of the government, it fluctuated like Sensex but managed to keep the economy rate under control. The government kept itself engaged with the public and hence capitalizes on the support of the perspective voters. Social media tools like Twitter not only remained the source of political information but also reached thousands of millions because of the popularity and presence of incumbent leaders on different forums of social media.

\section{REFERENCES \& BIBLIOGRAPHY}

Agrawal, Yogesh Kailashchandra (2017). Goods and Services Tax and Its Impact on Indian Economy. Journal of Business and Management (IOSR-JBM), Volume 19, Issue 10. Ver. VI., PP 26-30

Arora, Sant Lal, \& Kundu, Amitabh. (2015). Atal Pension Yojana. Economic and Political Weekly, 53(19), 7-8.

AZAM, K. (1977). THE SIXTH GENERAL ELECTIONS : A STUDY OF THE ELECTION MANIFESTOS OF THE NATIONAL PARTIES. The Indian Journal of Political Science, 38(3), 375-394. Retrieved December 5, 2020, from http://www.jstor.org/stable/41854806

Bala, Madhu, GST in India and its Impact on Indian Economy (February 2, 2018). Madhu Bala (2018, February 2). GST in India and its Impact on Indian Economy. Paper presented at Conference: GST Impact on Indian Economy Conference, Hindu Girls College, Jagadhari (Haryana), India, Available at SSRN: https:// ssrn.com/abstract=3555294

Banik, Nilanjan, \& Raman, G. Venkat. (2019). Reading Between the Lines, from Pulwama to the Balakot Airstrike. The Wire. Retrieved December 5, 2020, from https://thewire.in/security/pulwamabalakot-airstrike-india-paackistan

Biswas, A(2019), How much do election manifestos matter? - Telegraph India. (n.d.). Retrieved December 5, 2020, from https://www.telegraphindia.com/opinion/ how-much-do-election-manifestosmatter/cid/1692165

Biswas, A., Ingle, N., \& Roy, M. (2014). Influence of Social Media on Voting Behavior. Journal of Power, 2, 29.

BJP releases its Manifesto for 2014 elections. Narendra Modi hails it as a step ahead in the BJP's focus on good governance and development. (n.d.). Www.Narendramodi.In. Retrieved December 5, 2020, from 
https://www.narendramodi.in/bjpreleases-its-manifesto-for-2014-electionsnarendra-modi-hails-it-as-a-step-ahead-inthe-bjps-focus-on-good-governance-anddevelopment-6110

Deb, Rajat \& Sarma, Santanu. (2016). Picturing How PMSBY \& PMJJBY Matters. Economic and Public Policy. 1. 10.2139/ssrn.3482401.

DelhiApril 13, I. T. W. D. N., April 13, 2019UPDATED:, \& Ist, 2019 20:40. (n.d.). How Modi ministries have fared since 2014: A report card. India Today. Retrieved December 5, 2020, from https://www.indiatoday.in/elections/lok -sabha-2019/story/narendra-modiministries-word-achievement-2014-reportcard-1500919-2019-04-13

Dutta, P. K. May 29, 2018UPDATED:, \& Ist, 2018 14:06. (n.d.). 4 years of Modi Sarkar: Report card of promises kept. India Today. Retrieved December 5, 2020, from https://www.indiatoday.in/india/story/ 4-years-of-modi-sarkar-report-card-ofpromises-kept-and-missed-1241499-201805-25

Four years of Modi government: Hits \& misses: 4 years of Narendra Modi explained in 10 charts-The Economic Times. (n.d.). Retrieved December 5, 2020, from

https://economictimes.indiatimes.com/n ews/politics-and-nation/a-statisticalanalysis-of-four-years-of-narendra-modigovernment/articleshow/64335725.cms

Garg, Rahul. (2016). Impact of GST on Indian Economy - Re-Tales by Rahul Garg | ET Retail. ETRetail.Com. Retrieved December 5, 2020, from http://retail.economictimes.indiatimes.co $\mathrm{m} /$ re-tales/impact-of-gst-on-indianeconomy $/ 1525$

George, Deepti. (2015). Pradhan Mantri Mudra Yojana. Economic and Political Weekly, 55(7), 7-8.

Ghosh, Deepshikha. (2016). PM Narendra Modi, Praising Army For Surgical Strikes, Draws Comparison To Israel. NDTV.Com. https://www.ndtv.com/indianews/everyone-talking-about-our-armynow-says-pm-narendra-modi-1475678
Haidar, S., \& Peri, D. (2019, February 26). India bombs Jaish camp in Pakistan's Balakot. The Hindu. https://www.thehindu. com/news/national/air-strikes-hitbalakot-in-pakistan-initial-assessment-100hit-sources/article26373318.ece

Halarnkar, S. (2018). Modi has over-promised and under-delivered, but you may have been too distracted to notice [Text]. Scroll.In; https://scroll.in. Retrieved December 5, 2020, from https://scroll.in/article/869570/modihas-over-promised-and-under-deliveredbut-you-may-have-been-too-distracted-tonotice

jose, tojo. (2017, August 2). Demonetisation: An impact assessment IndianEconomy.net. Indian Economy. https://www.indianeconomy.net/splclas sroom/demonetisation-an-impactassessment/

Kelkar, A. C., Sanjana Mulay, Mrudula. (n.d.). Understanding the impacts of India's LED bulb programme, "UJALA" Prayas(Energy Group). Retrieved December 5, 2020, from https://www.prayaspune.org/peg/publi cations/item/354-understanding-theimpacts-of-india-s-led-bulb-programmeujala.html

Kumar, Alok Prasanna, A Decade of Decay. (2015). Economic and Political Weekly,55(3),7-8.

Kumar, S. (2019, September 29). Constructive criticism of government. The Hindu. https://www.thehindu.com/opinion/ope n-page/constructive-criticism-ofgovernment/article29542527.ece

Kushwaha, H., Kumar, A., \& Abbas, Z. (2018). Impact of Demonetisation on Indian Economy: A Critical Study. International Journal of Management Studies, V(2(7)), 25. https://doi.org/10.18843/ijms/v5i2(7)/04

G. Manikandan, G. Anandaraju and B. Karthikeyan, "A Candidate Aware Internet Voting System For Indian Scenario," 2020 6th International Conference on Advanced Computing and Communication Systems (ICACCS), Coimbatore, India, 2020, pp. 783-786, doi: 10.1109/ICACCS48705.2020.9074158. 
Mastakar, Rohan,(2017), Happy Birthday PM Modi: Here are 10 promises you haven't fulfilled. Retrieved December 5, 2020, from https://www.freepressjournal.in/ $\mathrm{cmcm} /$ happy-birthday-pm-modi-here-are-10promises-you-havent-fulfilled

McCONNELL, A. (2010). Policy Success, Policy Failure and Grey Areas In-Between. Journal of Public Policy, 30(3), 345-362. https://doi.org/10.1017/S0143814X10000 152

O'Cass, A., \& Pecotich, A. (2005). The dynamics of voter behavior and influence processes in electoral markets: A consumer behavior perspective. Journal of Business Research, 58, 406-413. https://doi.org/10.1016/j.jbusres.2003.08. 003

Raghotham,S,Das, G.K, Nayak, V, (2019) Modi's 5 years: A report card | Deccan Herald.

https://www.deccanherald.com/specials /sunday-spotlight/modi-s-5-years-areport-card-726064.

Ratna, A. (2007). IMPACT OF COALITION POLITICS ON CONSTITUTIONAL DEVELOPMENT OF INDIA. The Indian Journal of Political Science, 68(2), 337-354. Retrieved December 5, 2020, from http://www.jstor.org/stable/41856331

Reporter, B. S. (2014, April 7). BJP manifesto for Lok Sabha elections: Top Highlights. Business Standard India. https://www.businessstandard.com/article/elections-2014/bjpmanifesto-for-lok-sabha-elections-tophighlights-114040700183_1.html

Reporter, S. (2017, September 17). Modi's election promises remain on paper, says Narayana. The Hindu. https://www.thehindu.com/news/natio nal/andhra-pradesh/modis-electionpromises-remain-on-paper-saysnarayana/article19701387.ece
Sen, S. (2019, December 18). Data | How effective has the Pradhan Mantri Ujjwala Yojana been. The Hindu. https://www.thehindu.com/data/datahow-effective-has-the-pradhan-mantriujjwala-yojana-been/article30338388.ece

Sen, Sudhi Ranjan., \& Masoodi, Nazir. (n.d.). Army Says Ready For Any "Misadventure" From Across Line Of Control. NDTV.Com. Retrieved December 5, 2020, from https://www.ndtv.com/indianews/ prepared-to-deal-with-anymisadventure-from-across-loc-army1475781

Service, I.-A. N. (2014, April 7). Ram temple, Article 370 in BJP manifesto. India News, Breaking News, Entertainment News । India.Com.

https://www.india.com/election2014/bjp-election-manifesto-2014-ramtemple-construction-article-370-highlightsof-the-election-manifesto-35278/

Shah, Ruchika, 2019, Analysis: BJP Manifesto Is A Repeat Of 2014's Promises. (n.d.). Forbes India. Retrieved December 5, 2020, from

https://www.forbesindia.com/article/po ll-vault/analysis-bjp-manifesto-is-arepeat-of-2014s-promises/52989/1

Sharma, V., \& Sarathe, D. O. P. (2017). Analytical View on Pradhan Mantri Jeevan Jyoti Bima Yojana. 5, 4.

Singh, Dr Sutinder*. (2017). Demonetization And Its Impact On Indian Economy. https://doi.org/10.5281/ZENODO.10420 98

Waykole, M. V. (2019). Analysis on Pradhan Mantri Awas Yojna Implementation for Rural India Empowerment and Development. 6(6), 3.

Yadawar, S. (2020). AYUSHMAN BHARAT PRADHAN MANTRI JAN AROGYA YOJANA: PERFORMANCE SO FAR AND CHALLENGES AHEAD. 6, 11. 


\section{Website Links}

http://vaidicslucknow.com/wp-content/uploads/2017/01/complete-list-of-schemes-launched-bynarendra-modi-government.pdf

http://www.nsiindia.gov.in/internalpage.aspx?Id_Pk=146

http://www.nsiindia.gov.in/InternalPage.aspx?Id_Pk=89

https://www.dailyo.in/politics/narendra-modi-achievements-report-card-ayushman-bharatsanitation/story/1/29364.html

https://www.indiatoday.in/education-today/gk-current-affairs/story/26-important-governmentschemes-narendra-modi-government-divd-1592157-2019-08-27

https://www.jagranjosh.com/general-knowledge/important-schemes-launched-by-the-modigovernment-1549976147-1

https:/ / www.livemint.com/news/india/atal-pension-yojana-enrolment-crosses-2-crore-mark-aimsto-add-25-lakh-by-march-11575876612776.html

https://www.thedrum.com/opinion/2019/05/07/why-does-india-prime-minister-narendra-modirely-social-media-so-much

https://www.thehindu.com/news/national/andhra-pradesh/modis-election-promises-remain-onpaper-says-narayana/article19701387.ece

https://www.thehindubusinessline.com/news/national/comparing-2014-2019-manifestoes-of-

bjp/article26772496.ece 